\title{
Edward Said's Memoir Out of Place: Postcolonial Tenets, Dissonant Voices, and Divided Loyalties
}

\author{
Shadi S. Neimneh ${ }^{1} \&$ Halla A. Shureteh ${ }^{1}$ \\ ${ }^{1}$ Department of English, The Hashemite University, Zarqa, Jordan \\ Correspondence: Shadi S. Neimneh, Department of English, The Hashemite University, Zarqa, Jordan.
}

Received: June 8, 2021

doi:10.5430/wjel.v11n2p19
Accepted: July 9, $2021 \quad$ Online Published: July 19, 2021

URL: https://doi.org/10.5430/wjel.v11n2p19

\begin{abstract}
Edward Said's Out of Place (1999), a memoir written after his diagnosis with leukemia in 1991, was begun in 1994 to document his sense of cultural displacement and imminent death. This article examines the divided loyalties and dissonant voices Said vents in this book through the lens of cultural theories. It argues that such a conflicting vision can provide a proper context for understanding Said's contributions to cultural studies and literary theory via the construction of the other, the out of place, at the levels of language, religion, environment, and homeland. Said presents himself as a postcolonial subject par excellence with divided loyalties and "unhomely" feelings. He uses a confessional mode to convey a constant sense of exile and identity crisis. Said's life negotiated the postcolonial parlance he preached in his academic life, which offers a unique case on the relationship between theory and practice. The memoir emerges not only as an autobiographical text but equally as a contribution to literary theory and overlapping postcolonial discourses. Thus, this autobiographical memoir is useful for the literature classroom due to its theoretical value as well as non-fictional import.
\end{abstract}

Keywords: Edward Said, Out of Place, postcolonial theory, dissonant voices, identity, non-fiction memoir

\section{Introduction}

Edward W. Said's non-fictional memoir Out of Place (1999) is a book on exile, and on being out of place. The book details multiple forms of exile (like language-related exile and cultural forms of exile associated with frequent departures and arrivals in different cities) and expresses ambivalent feelings of homesickness, physical inadequacy, and nostalgia. Hence, Said begins the memoir with the assertion that "the overriding sensation [he] had was of always being out of place" (Said, 2000, p. 3). The private life Said confesses, however, is not more significant than his cultural and postcolonial concerns. The result is not an autobiographical book per se, but a non-fictional work on cultural criticism. This article explores both aspects of Said's work within relevant historical, political, and theoretical contexts. Ultimately, the article probes the relationship between postcolonial theory and cultural criticism on the one hand and the life of the committed postcolonial intellectual on the other. It looks at the connection between literary theory and its praxis by the critic who embodies the ideals of the theory (s)he masters. While scholars conventionally engage theory (postcolonial and cultural theory in this case) to explicate individual literary works in what is commonly called practical or applied criticism, this article adopts an alternative approach of looking at the relationship between non-fiction and theory, between the theory and the theorist as the postcolonial intellectual. Therefore, this memoir can be richly used in the literature classroom for both its theoretical nuances and literary, non-fictional qualities.

Colonial struggle is never "dead," continuing in regions like Tibet, Kashmir, and the Middle East (Habib, 2005, p. 738). Therefore, issues of home, diaspora, migration, domination, and anti-colonial struggle, together with their articulation and contestation, remain pivotal questions in postcolonial studies. Said's Out of Place addresses exile and displacement. Hence, his acclaimed essay "Reflections on Exile" which elaborates a theory of exile serves as a good introduction to our argument: "Exile is strangely compelling to think about but terrible to experience. It is the unhealable rift forced between a human being and a native place, between the self and its true home: its essential sadness can never be surmounted" (Said, 2002, p. 137). He discusses exile in terms of insecurity, solitude, rootlessness, and being "always out of place" (p. 143). Thus, Said articulates the main theme he took up in his memoir. With his own case in mind, he discusses exile in terms of fatalism and determinism rather than choice; "you are born into it," Said writes, "or it happens to you" (p. 146). Exiles are not allowed to return home; they are 
banished and forced to be outsiders, but they keep juxtaposing two worlds against each other. Said explains: "Thus both the new and the old environments are vivid, actual, occurring together contrapuntally" (p.148). So, exiles are cut off from their past lives yet constantly remember a traumatic past. In the case of Palestinians, Said articulates the irony of being exiled at the hands of historic exiles (2002, p. 141), i.e. the Jews. In line with the psychological theories on loss, difficult separation, and mourning, Said argues that "Exile is predicated on the existence of, love for, and bond with, one's native place; what is true of all exile is not that home and love of home are lost, but that loss is inherent in the very existence of both" (p. 148). Importantly, Said discusses exile with relation to double vision and contrapuntality: "Most people are principally aware of one culture, one setting, one home; exiles are aware of at least two, and this plurality of vision gives rise to an awareness of simultaneous dimensions, an awareness that - to borrow a phrase from music - is contrapuntal ", (p. 148; emphasis original). By reading Said's memoir as a story of loss of homeland and exile, this article interrogates the text's postcolonial relevance and sheds light on the interrelationship between the postcolonial intellectual and postcolonial tenets. Said's memoir embodies his thoughts on exile, and his conception of plural visions, double articulations, and divided loyalties. The memoir epitomizes Said's contrapuntal stance on cultural affiliations and identity politics.

Said's memoir had its root trigger agent in a fatal diagnosis he received in 1991 that he had lymphatic blood cancer. He began to work on it in 1994 when he began medical treatment (chemotherapy) and realized that he entered the last phase of his life. Writing the memoir corresponded to the developing phases of his illness and drew heavily on his memory of time and place. In the Preface, Said says: "Several years ago, I received what seemed to be a fatal medical diagnosis, and it therefore struck me as important to leave behind a subjective account of the life I lived in the Arab world, where I was born and spent my formative years, and in the United States, where I went to school, college, and university" (2000, p. xi). It is ironic that his phone call to his wife in America while he was in London joining a conference for Palestinian intellectuals and activists to support the right to self-determination revealed that the results of his blood analysis require attention by a blood specialist. Hence, his attempts to attach himself to his Palestinian roots were encountered by his need to memorialize his past life and dig for the buried self in order to leave a document about his life prior to the year of 1951 when he left Cairo to America and spent about the rest of his life in American cities. While he felt exiled in New York where he mainly lived and taught, he was not able (for political reasons) to visit the Cairo of his childhood for many years until 1998, nor could he visit the Jerusalem of his early childhood because the Palestine he knew was replaced by Israel. Said's personal life arguably shaped his postcolonial thought and his contrapuntal intellectual vision expressed in this memoir and in his other writings.

Throughout his life, Said lived this state of conflict of being torn between dissonant languages, cities, religions, and cultures. He felt that his identity was one in a state of transience, and that he was out of place, a fact evidenced by his constant need to travel. He never felt fully at home in America or related to the vague, difficult past of his childhood. Exile, insecurity, and identity problems form the cultural crux of the memoir. In his words, "Being myself meant not only never being quite right, but also never feeling at ease, always expecting to be interrupted or corrected, to have my privacy invaded and my unsure person set upon" (2000, p. 19). Said's personal life essentially negotiated the postcolonial parlance he preached and theorized in his academic life, which offers a unique vision on the relationship between theory and practice. He embodied the intricate relationship between "culture and imperialism," and it is no wonder that he wrote a book with that title. Said's personal (diasporic) life mirrored his cultural criticism, and in particular his postcolonial contributions. Thus, this article reveals Said to be an ideal representative of the diasporic postcolonial intellectual who was born and raised in the East yet whose work and training were mainly Western. While he absorbed the main tenets of Western philosophy, literature, and literary theory, reacted to them in his scholarly work, and taught them, he often tackled them in his counter-discourses and presented them as formative influences to his contrapuntal position. Out of Place remains informed by Said's Foucauldian understanding of the interrelationship between knowledge and power and the primacy of discourse as a political tool in imperial politics. Said, as a Palestinian critic, "views his own attempt to understand the cultural work of Orientalism as a site of resistance to the hegemony of Western values and ideals" (Richter, 2007, p. 1761). In fact, Said's memoir proves that he understood his own life in ambivalent terms of involvement in such Western values and a necessary resistance to them.

\section{Exile and Diaspora: Theoretical and Historical Contexts}

There are interrelated theoretical and intellectual models we can use to approach Said's Out of Place. The theoretical richness of Said's text confirms its status as a cultural text with manifest postcolonial themes, especially those related to exile, contrapuntality, and ambivalence. While some critics like Anna Bernard have already confirmed that this autobiographical, non-fictional memoir addresses "the same commitments to Palestinian national identity, indigeneity, and statehood" that he advocated elsewhere (2013, p. 43), the intricate web of intertextual relations and 
allusions the memoir consciously or unconsciously forms still needs contextualization for the insights they yield to the literature classroom. The memoir is relevant, it is argued, by virtue of its status as a postcolonial treatise as well as a non-fictional narrative. Said's assertion in Orientalism that he always viewed himself as an oriental subject works here as both texts depict his bipolar cultural vision. Said contends:

Much of the personal investment in this study derives from my awareness of being an 'Oriental' as a child growing up in two British colonies. All my education, in those colonies (Palestine and Egypt) and in the United States, has been Western and yet that deep early awareness has persisted. In many ways, my study of Orientalism has been an attempt to inventory the traces upon me, the Oriental subject, of the culture whose domination has been so powerful a factor in the life of all Orientals. (1979, p. 25)

The memoir reworks the radical dichotomies between the East and the West in Said's Orientalism, and in particular his introduction in which he claimed that the West has defined itself as the antithesis of the East and its "cultural contestant, and one of its deepest and most recurring images of the Other" (Said, 1979, p. 1). The Orient is the other of Europe for Said, and this relation of opposition is further illustrated when he argues that the Orient has helped "define Europe (or the West) as its contrasting image, idea, personality, experience" (pp. 1-2). Hence, European culture "gained in strength and identity by setting itself off against the Orient as a sort of surrogate and underground self" (p. 3). The assumed "ontological and epistemological" (p. 2) differences become the ground for moral and metaphysical differences between the two worlds that Said lived in, the East of his childhood and the West of his mature life and professional career, the Orient and the Occident. One of Said's books written before Out of Place and whose writing probably overlapped with the early stages of writing this book is Culture and Imperialism (1993). In this book, Said confirms the main theme taken up in this memoir. He asserts that living on both sides of the imperial divide between the Arab culture of his childhood and the Western culture of his education sharpened his feelings of being an exile. He dubs Culture and Imperialism as an "exile's book":

I have felt that I belonged to both worlds, without being completely of either one or the other. During my lifetime, however, the parts of the Arab world that I was most attached to either have been changed utterly by civil upheavals and war, or have simply ceased to exist. (1993, pp. xxvi-xxvii)

Said's life, hence, can be viewed as an attempt to mediate between both worlds. This contrapuntal vision of a cultural schism between the East and the West helped in the formation of the contradictions and ambivalences that color Said's memoir. Within the same context of a binary cultural vision, a similar point can be traced in Abdul JanMohamed's discussion of the "manichean allegory" as the central trope of the colonialist discourse (1985, p. 61) whereby racial differences acquire imposed meanings. This allegory is defined in oppositional terms as "a field of diverse yet interchangeable opposition between white and black, good and evil, superiority and inferiority, civilization and savagery, intelligence and emotion, rationality and sensuality, self and Other, subject and object" (p. 63). The divide Said constructs between the East of his infancy and early life versus the West of his education and professional life remains a colonial one governed by relations of dominance and dependence. Viewed literally or metaphorically, Said's life was an embodiment of this "Manichaeism," growing up as a Christian child among the Muslim majority in Palestine and Egypt. Living at the borderland of two religions, Said experienced another level of dualism.

As Abdul JanMohamed (1985) contends, "The dominant model of power-and interest-relations in all colonial societies is the manichean opposition between the putative superiority of the European and the supposed inferiority of the native" (p. 63). Said's colonial education enhanced his feelings of difference and inferiority, and the two worlds Said depicted where essentially irreconcilable, and so they remain today. When Said went to a school for American children in Cairo in 1946, he had feelings that he did not belong there as an American citizen and that his presence there was just a consequence of his father's citizenship as an American businessman. Neither in his dress nor in his meals did he feel he was an American, which increased his "doubt and shame that [he], an American child, ate a different food, which no one ever asked to taste, nor asked [him] to explain" (Said, 2000, p. 81). The American children are described as "totally unfamiliar, loud, unself-conscious American children in gaily colored shirts, skirts, and shorts" (p. 80), yet Said had to pretend he had an American name while concealing his "perfect command of what was [his] mother tongue in order to fit in better with the inane formulas given out to American youngsters" (Said, 2000, p. 82). The English preparatory school, Gezira, also intensified his feelings that he was not an English man. In the American school, he experienced the tension between his American citizenship and his Arab identity that endowed him with shyness and discomfort. He felt the huge gap between the Egyptian local environment and the American one. His school years not only made him feel alienated, but also out of place in both worlds. His schooling in English colonial schools and American ones was one reason behind his "already uncertain sense of self" (p. 83) as 
an Arab boy in such schools.

In 1897, W. E. B. Du Bois-the African American historian and sociologist-published an article in The Atlantic magazine on the strivings of the "Negro" people, which later became an essential chapter of his book The Souls of Black Folk entitled "Of Our Spiritual Strivings," where he articulated the problematics of conflicted identity African Americans have experienced in America, in a history of oppression and discrimination. He labelled this sensation as "double consciousness" and defined it in terms of "contempt and pity" and "warring ideals" between his "Negro" blood and his Americanism (1903, pp. 2-3). Du Bois pinpoints the difficulties of assimilation in white America versus maintaining the cultural integrity of the black identity. This cultural model is a universal one applying to the darker races in the political thought of Du Bois as manifested in his other writings. It is also handy for other contexts whereby the marginalized encounter dominant cultures. Said constantly had the "double consciousness" of multiple identities and complicated colonial history. His identity as an Arab with Palestinian roots was incongruent with the colonial education he received and the American lifestyle he led, and he lived on the borderline between conflicting cultures and identities, a zone described as the "out of place." In his words, the overriding sensation he had "was of always being out of place. Thus it took me about fifty years to become accustomed to, or, more exactly, to feel less uncomfortable with, 'Edward,' a foolishly English name yoked forcibly to the unmistakably Arabic family name Said" (2000, p. 3). Said's difficult yet persistent awareness of the Arab and Western parts of his identity made him experience a state of "double consciousness" of the sort Du Bois articulated.

In her semi-autobiographical book Borderlands/La Frontera: The New Mestiza (1987), Gloria Anzaldúa adopts a unique style of mixing prose and poetry to discuss the experience of being in the margins or living in a state of transition between cultures and languages without being able to feel at ease or claim a single language/culture. This life on the border, on the frontier between languages and cultures, is one in the shadows. Anzaldúa brings in her personal life as a woman of color and lesbian to explore the position of the new "mestiza" as a woman of mixed race with Latin/Native American and European roots. Borderline spaces between Mexico and America are hybrid ones and part of both worlds. For Anzaldúa, a borderland is "a vague and undetermined place created by the emotional residence of an unnatural boundary. It is in a constant state of transition. The prohibited and forbidden are its inhabitants" (p. 3). Despite differences in the immediate context, gender variables, and historical variations, Said also experienced this "borderline/borderland" feeling at mental and intellectual levels and not only with respect to spatial dislocation. Anzaldúa continues that a border culture is a "shock culture" (p. 33) found when two worlds merge: "Tension grips the inhabitants of the borderlands like a virus. Ambivalence and unrest reside there and death is no stranger" (p. 4). In line with Said's preoccupation with exile in Out of Place, Anzaldúa writes: "As a mestiza I have no country, my homeland casts me out" (p. 80). Arguably, Said felt more nostalgic for a homeland, especially late in his life. Despite his complicated family history and the nature of his father's business outside Palestine, he felt he was cast out of his homeland due to colonial policies and subsequent Zionist plans. For example, Said mentions in the Preface that a visit to Jerusalem in 1998 after completing the manuscript of the memoir made him discover "anew that what had been a network of towns and villages in which all members of my extended family had once lived was now a series of Israeli locales - Jerusalem, Haifa, Tiberias, Nazareth, and Acre-where the Palestinian minority lives under Israeli sovereignty" (2000, p. xii). So, although he lived on the borderline between the East and the West (emotionally, intellectually, and figuratively if not literally), Said felt he had no "home."

Another significant intervention comes from Homi Bhabha who discusses cultural encounters in terms of negotiation and the hybrid zone. Bhabha deconstructs notions like "cultural purity" and "stereotype" and favors, instead, "ambivalence" and "mimicry" to allow for the emergence of a hybrid identity in the productive space of cultural enunciation: "It is in the emergence of the interstices-the overlap and displacement of domains of difference-that the intersubjective and collective experiences of nationness, community interest, or cultural value are negotiated" (1994, p. 2; emphasis original). Personal and cultural identity undergoes a process of transformation as a result of migration, travel, and cultural contact: "it is the space of intervention emerging in the cultural interstices that introduces creative invention into existence...there is a return to the performance of identity as iteration, the re-creation of the self in the world of travel, the resettlement of the border-line community of migration" (p. 12). Bhabha's theory on the hybrid third space, like Anzaldúa's borderland model, helps us understand the cultural position of Said as articulated in his memoir, that of being trapped between different locations, antagonistic cultures, and diverse linguistic affiliations. However, since Said related the beginning of this memoir to the onset of his disease, his nostalgic feelings for a homeland, and his growing feelings of being an outsider, his position with relation to hybridity as a fruitful force of cultural enunciation should be problematized. He did produce culturally, but the memoir is pessimistic and communicates a sense of a "difficult" hybridity.

Anxiety, moodiness, and feelings of banishment characterized Said's reactions to an inevitable life of travel. His Published by Sciedu Press 
feeling of being displaced contributed to a lack of solid identity. Instead, Said repeatedly experienced himself as "a cluster of flowing currents" (2000, p. 295) always in motion and without a sense of harmony. It is no wonder that he ends this memoir with this bleak statement: "With so many dissonances in my life I have learned actually to prefer being not quite right and out of place" (p. 295). Evoking Bhabha's engagement with "mimicry" and the ambivalence of colonial discourse in The Location of Culture, the "almost the same, but not quite" logic, Said articulates his sense of being a stranger, neither quite American nor simply an Arab. For Bhabha, the articulation of cultural differences produces identity in-between different positions related to class, race, and gender. The in-between spaces "provide the terrain for elaborating strategies of selfhood-singular or communal-that initiate new signs of identity, and innovative sites of collaboration, and contestation, in the act of defining the idea of society itself" $(1994$, p. 2). However, this new identity that emerges in the third space out of cultural negotiation was conflictual and unhomely for Said. A sense of fear and uprootedness always accompanied Said despite his personality traits and rich lifestyle. Against the model of positive hybridity, Bhabha discusses unhomeliness in terms of displacement where "the borders between home and world become confused; and, uncannily, the private and the public become part of each other, forcing upon us a vision that is as divided as it is disorienting" (1994, p. 13). Bhabha continues that with unhomeliness the private and the political become intertwined: "The unhomely moment relates the traumatic ambivalences of a personal, psychic history to the wider disjunctions of political existence" (p. 15). Unhomeliness for Bhabha is "the condition of extra-territorial and cross-cultural initiations" (p. 13). On the other hand, those "initiations" were tragic or unfortunate in the case of Said who says that the discrepancy between his private and public lives was unsurmountable:

So beginning in America I resolved to live as if I were a simple, transparent soul and to speak about my family or origins except as required, and then very sparingly. To become, in other words, like the others, as anonymous as possible. The split between "Edward" (or, as I was soon to become, "Said"), my public, outer self, and the loose, irresponsible fantasy-ridden churning metamorphoses of my private, inner life was very marked. Later the eruptions from my inner self grew not only more frequent but also less possible to control. (2000, p. 137)

Bhabha has described the unhomely as a "paradigmatic" (post)colonial condition (1994, p. 13). Unhomeliness, rather than hybridity, might better characterize Said's sense of linguistic instability and his multiple yet difficult religious, cultural, and national self-contradictions: "I have retained this unsettled sense of many identities - mostly in conflict with each other-all my life, together with an acute sense of memory of the despairing feeling that I wish we could have been all-Arab, or all-European and American, or all-Orthodox Christians, or all-Muslim, or all-Egyptian, and so on" (2000, p. 5). His in-between life was characterized by different levels of displacement: "To me, nothing more painful and paradoxically sought after characterizes my life than the many displacements from countries, cities, abodes, languages, environments that have kept me in motion all these years" (2000, p. 217). Thinking about his habit of overpacking when traveling, he concludes that he had "a secret but ineradicable fear of not returning" (p. 217). To draw on the work of Bhabha again, Said felt "unhomed" in America. "To be unhomed" for Bhabha, "is not to be homeless, nor can the 'unhomely' be easily accommodated in that division of social life into private and public spheres" (1994, p. 13). Even in Cairo, the city which he loved the most, Said did not feel exactly at home (2000, p. 43). Constant travel confirmed his sense of exile, of being out of place. A life between Egypt, Lebanon, and America in his youth and adult years as well as distant memories of infancy in Palestine was an indication of a temporary life and an attempt to belong to a place or be attached to one although that was impossible, just like the multiple identities Said absorbed as Arab, Christian, and American.

In fact, the memoir is an effort at cultural resistance, an act of writing back to the imperial West. The terms Said uses to describe his contested cultural position evade the potentially positive conception of hybridity and weigh more towards the zone of enforced exile and "unhomeliness." His visits to the Arab world in his mature life only confirmed his separation from the world of his childhood, and his subsequent sense of exile. Said's argument in Culture and Imperialism is that Western culture mainly supported the underlying assumptions of Western imperialism. The literary/cultural factor was as important as the political and economic motives of imperialism. As a reaction to this imperial concern with narrative and discourse, Said contends: "nations themselves are narrations. The power to narrate, or to block other narratives from forming and emerging, is very important to culture and imperialism, and constitutes one of the main connections between them" (1993, p. xiii). Said invokes Bhabha's logic on nations as narrations to foreground a cultural discourse of resistance. Out of Place is Said's story not only of a personal life of an exiled academic but also the story of a lost nation that Said identified more with in times of sickness and old age. His act of writing this "postcolonial" memoir is a defiant act against silence. The memoir is the discourse of the subaltern written from the imperial center and in the dominant language of the colonizer, which gives the book the potential status of a "minor literature" tii that "subverts" Western culture from within and in its 
major language (English). In the words of Deleuze and Guattari, a minor literature is not written in a minor language; rather, it is "that which a minority constructs within a major language" (1986, p. 16). African-American literature written in English "deterritorializes" this language just as other minorities like people from Arab or Mexican descent can use English for "minor uses" (Deleuze and Guattari, 1986, p. 17) in different parts of the world. Deleuze and Guattari's argument becomes one for subaltern groups of minorities living in diaspora:

How many people today live in a language that is not their own? Or no longer, or not yet even know their own and know poorly the major language that they are forced to serve? This is the problem of immigrants, and especially of their children, the problem of minorities, the problem of a minor literature, but also a problem for all of us: how to tear a minor literature away from its own language, allowing it to challenge language and make it follow a sober revolutionary path? (1986, p. 19)

Although Said mastered English, he felt it was not his own, and he was often confused between English and Arabic as to which was his mother tongue. His colonial education forced him to use the master's language. Said describes his Victoria College life in Cairo as a replication of a declining British imperialism over Arab culture and Arabic language: "Being and speaking Arabic were delinquent activities at $\mathrm{VC}$, and accordingly we were never given proper instruction in our own language, history, culture, and geography. We were tested as if we were English boys, trailing behind an ill-defined and always out-of-reach goal from class to class, year to year, with our parents worrying along with us" (2000, p. 186). A member of the "inferior" minority of Christian Arabs in colonial Egypt, Said practiced the language of his colonial "masters" rather than the Arabic of his roots. His parents encouraged him to speak English and grow up as an American citizen, but that never made him feel fully American or English.

In his Introduction to the Arabic edition of the memoir, Said articulates the language differences between Arabic and English as establishing acute tension between two antagonistic worlds: the Arab world to which his family belongs and the history and environment of his early self as opposed to the colonial world of his education and professional writing career and acquired tastes, between what he was and what he became. This conflict between his Arab identity and American identity was a source of discomfort and dissonance. Said lived not only out of place but also out of language. He maintains:

I have never known what language I spoke first, Arabic or English, or which one was really mine beyond any doubt. What I do know, however, is that the two have always been together in my life, one resonating the other, sometimes ironically, sometimes nostalgically, most often each correcting, and commenting on, the other. (2000, p. 4)

The memoir was written in English as a language Said mastered, and it was translated into Arabic in 2000 about a year after its original publication in English, but Said's relationship with English was an ambivalent one. English was the language of the two main colonial empires that impacted Said's life: Britain and America. $\quad$ On the other hand, Said never lost touch with Arabic, speaking it during his travels to the Arab world and listening to it in use. In this memoir, he earnestly tries to use this autobiographical genre to culturally negotiate his life. In the words of Doaa Embabi, and being caught between languages and cultures, Said "engages in cultural translation of himself" (2017, p. 150). It is no wonder, hence, that his early life consisted of thinking and articulating in one language while simultaneously conjuring equivalents in another.

Victoria College, which Said attended between the age of fourteen and sixteen before he left Cairo for America, was an English school where he felt different and unknown. The traditional British colonial nature of the school made it impose the English language on its students while erasing Arabic language and culture. This augmented Said's identity crisis later in his mature life, for as Anzaldúa contends "ethnic identity is twin skin to linguistic identity" (1987, p. 81). Besides, Victoria College enhanced Said's knowledge of French and English yet suppressed his Arabic. As Said puts it, "Being and speaking Arabic were delinquent activities at $\mathrm{VC}$, and accordingly we were never given proper instruction in our own language, history, culture, and geography" (2000, p. 186). The school was a symbol for the declining colonial power of the British Empire. Although he mastered English, the growing up Said felt it was the language of "the hated British" (p. 198). He articulates this conflict of being a polyglot (speaking Arabic, English, and French) and how he would use a language while the corresponding vocabularies of other languages would rush to his mind: "While speaking English, I hear and often articulate the Arabic or French equivalent, and while speaking Arabic I reach out for French and English analogues, strapping them onto my words like luggage on an overhead rack, there but somehow inert and encumbering" (p. 198). However, the colonial British background would suppress his Arabic language as a forbidden, inferior language. Said reiterates his alienation from Arabic language and culture due to his colonial education and exilic life. "The basic split in my life," he asserts, "was the one between Arabic, my native language, and English, the language of my education and subsequent expression as a scholar and teacher, and 
so trying to produce a narrative of one in the language of the other-to say nothing of the numerous ways in which the languages were mixed up for me and crossed over from one realm to the other - has been a complicated task" (2000, pp. xiii-xiv). He found it difficult to communicate in English the rich associations and nuances of Arabic. The two languages mirroring each other in Said's mind are an instance of double consciousness. In fact, the act of writing this memoir in English was a constant reminder for Said of the Arab world which years have suppressed from his life and the Arabic language directly related to his life in Palestine, Egypt, and Lebanon.

If Out of Place is theoretically relevant to postcolonial discourse and minority studies, it is because it is an attempt to situate Said as a postcolonial diasporic intellectual. Feminist critic Gayatri Spivak once voiced the difficult position of the postcolonial diasporic critic in terms that can be applicable to Said. In an interview in 1987, Spivak claimed: "The space I occupy might be explained by my history. It is a position into which I have been written. I am not privileging it, but I do want to use it. I can't fully construct a position that is different from the one I am in" (1990, p. 68). Spivak here vents the inseparability between the personal life of the postcolonial diasporic critic and history. As with exile, this position is not a matter of choice. It is an imposed one by cultural, political, and historical variables beyond the critic's private life. Like Spivak, Said could not present an alternative vision other than that of double articulations, dissonant voices, and divided loyalties. This analogy with Spivak helps us understand the space of the postcolonial critic who used that very position in his/her postcolonial approach. Hence, it is difficult to discuss the life or work of Said without thinking about matters of cultural and linguistic dislocation or the borderline experiences of cultural conflations.

Functioning as a character and a narrator in Out of Place, Said remembers the Palestine of his childhood (which now became Israel with new occupants in its land and homes). This political context is necessary for understanding the memoir. Said mentions such a fragmented, doubtful background in the turbulent Arab world and belligerent Europe: "I found myself telling the story of my life against the background of World War II, the loss of Palestine and the establishment of Israel, the end of the Egyptian monarchy, the Nasser years, the 1967 War, the emergence of the Palestinian movement, the Lebanese Civil War, and the Oslo peace process" (2000, p. xiii). The private life of Said corresponded to the tragic story of his nation, which gives the memoir an allegorical dimension of the sort we often encounter in "third-world" literature. According to Fredric Jameson (1986), many third-world intellectuals have been obsessively occupied with "the national situation" in the third world (p. 65). Jameson defines this third world as countries which have gone through "the experience of colonialism and imperialism" (1986, p. 87). He makes the generalization that third-world cultural productions are essentially allegorical and can be read as "national allegories" erasing the split between the private and the public, the personal and the political. For Jameson, "the story of the private individual destiny is always an allegory of the embattled situation of the public third-world culture and society" (p. 69; emphasis original). Said's memoir, non-fictional as it is, remains a cultural production by an intellectual with Middle Eastern roots, and Said suffered from the experience of "colonialism and imperialism" as Jameson describes it, even if he had a problematic relationship to the colonial Western culture since he held American citizenship through his father and lived most of his adult life there. Said's autobiographical memoir can be allegorically read as a national story of loss; it is more than a private story of a difficult childhood or a sustained feeling of exile. The postcolonial subtext is fused with the personal story of a life divided across the imperial divide.

The memoir is written against the British Mandate in Palestine and the fall of many parts of Palestine in 1948 in the hands of the Zionist Haganah groups, especially in the western parts of Jerusalem in which he was born. At the age of twelve, Said left Palestine and moved in 1947 to Cairo. Although he did not personally witness the events of the Nakba, he describes how the English suddenly left Palestine in 1948 to Zionist groups. The family dealt with that loss in a hesitant shy way, trying to repress that tragic past from the family history whenever possible. For example, Said mentions how his father usually avoided the Palestine issue at family gatherings although attempts to repress the past were often encountered by the lived reality of dislocation and poverty faced by refugees in Cairo, Beirut, Jordan and elsewhere. Said maintains: "The subject of Palestine was rarely talked about openly, although stray comments by my father suggested the catastrophic collapse of a society and a country's disappearance" (2000, p. 116). The loss of land equally meant the loss of abundance, trees, and financial security. Expressing his surprise at a past event yet a newfound preoccupation, Said says: "It seems inexplicable to me now that having dominated our lives for generations, the Problem of Palestine and its tragic loss, which affected virtually everyone we knew, deeply changing our world, should have been so relatively repressed, undiscussed, or even remarked on by my parents" (p. 117). Through his aunt, Nabeeha, Said was able to see the repercussions of Nakbah on Palestinian refugees in Cairo. His aunt lived in 1948 close to them and helped many poor and sick refugees, which countered his father's attempts to keep Said and his other daughters away from war and political tension. At the level of Said's close family, the topic of Palestine often remained prohibited. In fact, being born in Palestine caused problems to the family, especially in 
the case of Said's mother who did not carry an American citizenship, and had to change her birthplace from Nazareth to Cairo to get a Lebanese citizenship. Ironically, she died of cancer like him and was buried in America during one of her treatment visits. Therefore, the memoir brings to surface what Said's family tried to suppress from his memory, i.e. national politics as embodied in the issue of Palestine.

Said's last year in Palestine, 1947, witnessed the "signs of impending crisis" with Jerusalem being divided into "zones maintained by British Army and police checkpoints" (2000, p. 107). Years after the tragic loss, Said mourns the loss of Jerusalem to European immigrants who "conquered the city and have made it the unique symbol of their sovereignty, with no place for Palestinian life" (p. 111). The British mandate gave way to a Zionist settlement in Palestine. Hence, the memoir can be read from a postcolonial perspective as an act of "bearing witness" to the complexities and traumas contingent on being (an exiled) Palestinian. ${ }^{\text {iii }}$ Sickness and approaching death made Said more nostalgic to the past of his childhood and made him reflect on his politically fraught academic career. It is difficult to study Said's memoir without reference to national politics and the overriding theme of exile contingent on being trapped between two contrapuntal cultures. Hence, writing this memoir was in part an attempt to counter the effacement of the question of Palestine from his memory after years of successful teaching and research at prestigious academic institutions in the USA and a life in New York. Since the loss of Palestine was a historical reality Said grew up to experience, the act of writing was a nostalgic attempt to restore such a lost world.

Although Said was uncertain about his cultural identity, his physical identity was also at stake. He felt alienated from his domineering father whom he depicts as a strong authoritative father with a massive chest and back (2000, p. 55) in contrast to a timid, neurotic son conscious of his "innumerable physical defects" (p. 55) like shortsightedness, tall figure, big hands, soft abdomen, and humpback. The father's "powerful virility" made Said shrink in anxiety (p. 160). A sense of fear and anxiety ensued due to this physical uncertainty. Enhancing the memoir's psychological import and confessional spirit, Said contends: "my father came to represent a devastating combination of power and authority, rationalistic discipline, and repressed emotions; and all this, I later realized, has impinged on my whole life, with some good, but also some inhibiting and even debilitating effects" (p. 12). He suffered under the discipline his father imposed on him and his parents' expectations. For Said, identity conflict was a mixed feeling with cultural and social roots compounded with bodily issues. He was the object of his father's criticism and his mother's crippling concern for his weak, loose body (his broad chest, his big hands and long fingers, and hunched back). Bodily limitations made him distrust another level of identity, not the interpersonal (social or cultural) but also the bodily. Conscious of his physical limitations, he became the marginalized figure, the insecure evasive Said as the self-effacing intellectual who did not like to watch himself on TV or read what others wrote about him. Hence, his psychic feelings of inferiority and marginalization were augmented by feelings of physical inadequacy and difference. Because he was insecure with his physical identity, Said's exile was twofold: cultural and physical. His increasing illness which the memoir documents, that of blood cancer (leukemia in particular), further marginalizes him. In his final years, Said was being pushed into the realm of ailments and disease. Accordingly, the memoir has elements of the illness narrative as some critics have argued (Neimneh \& Obeidat, 2015). Terminal illness was only one factor, among many others, which intensified his sense of cultural dislocation and being out of place.

\section{Conclusion}

In Said's childhood, both Palestine and Egypt were British colonies, and Said lived the complications of the Arab-Israeli war of 1948 after the end of the British mandate on Palestine. Out of Place reiterates major postcolonial themes Said had already voiced in works such as Orientalism and Culture and Imperialism or shorter articles-thus interrogating the relationship between the private and the public, the theory and the theorist. Said highlights the incongruity between his Arab second name (Said/Sa'eed) and his Anglicized first name (Edward), and he takes this to be an essential example of identity conflict. A life of contradictions he documents also involved his past life scattered between Palestine, Egypt, Lebanon and America. This contrast between such two worlds was also evident during his school years in Cairo where he felt the split between the colonial world of his English and American schools and the different Arab world outside the enclosed school system. Throughout, the memoir communicates a sense of discrepant attitudes, conflicting feelings, and discordant attachments. Said's depiction of this sense of identity loss, anxiety, and transience makes one think of Du Dois's famous question in The Souls of Black Folk: "How does it feel to be a problem?" (1903, p. 1). Likewise, Palestinians felt they were a problem in their exile, seeking official papers and work or travel permits inside or outside Palestine. ${ }^{\text {iv }}$ Said's memoir was an attempt to depict such a problem, the problem of the postcolonial diasporic intellectual.

Said wrote his memoir after his diagnosis with leukemia to document his continuous sense of displacement which lasted up to his death in 2003. Reading this memoir through a cultural perspective, the article has looked into the 
divided loyalties and dissonant voices Said expressed in this memoir and elsewhere. Such a conflicting vision provides a proper context for understanding Said's postcolonial contributions to cultural studies and literary theory. Hence, we have investigated the contributions of non-fiction (autobiography/memoir) to postcolonial rhetoric and literary theory via the construction of the other, the out of place, at the levels of language, culture, homeland, history, and residence. Said presented himself as a postcolonial subject with an acute sense of identity crisis. The fact that this self-representation comes from one of the most dominant cultural critics in the twentieth century makes us wonder if the diasporic cultural/postcolonial critic can ever escape their sense of exile and displacement. The article has tackled the relationship between non-fiction and literary theory, focusing on how a cultural critic uses a confessional mode to present himself as a postcolonial subject with divided loyalties and conjures an "unhomely" condition. Said's personal life (a diasporic, unhomely, hybrid one) negotiated the postcolonial parlance he embraced, which in turn establishes a unique vision on the relationship between theory and practice. Said's non-fictional memoir and his cultural/political contributions enrich each other and echo dominant postcolonial precepts. The postcolonial approach, unlike many other approaches, is more directly personal. Based on the significant personal, cultural, and political reflections of the book, Said's Out of Place is not simply a memoir; it is hybrid in form also having a cross genre - the borderlands genre - alternating between personal memories, autobiography, politics, history, and cultural theory. Hence, it easily lends itself to the literature classroom, in particular when the intersections between non-fiction and literary theory are involved.

\section{References}

Anzaldúa, G. (1987). Borderlands/La Frontera: The New Mestiza. San Francisco: Aunt Lute.

Bernard, A. (2013). Rhetorics of Belonging: Nation, Narration, and Israel/Palestine. Liverpool: Liverpool University Press. https://doi.org/10.2307/j.ctt5vjk1v

Bhabha, H. (1994). The Location of Culture. London: Routledge.

Deleuze, G., \& F. Guattari. (1986). Kafka: Toward a Minor Literature. (Trans. Dana Polan). Minneapolis: University of Minnesota Press.

Du Bois, W. E. B. (1903). The Souls of Black Folk. New York: Dover.

Durrant, S. (1999). Bearing Witness to Apartheid: J. M. Coetzee's Inconsolable Works of Morning. Contemporary Literature, 40(3), 430-463. https://doi.org/10.2307/1208885

Embabi, D. (2017). Translating the Self in Edward Said's Out of Place: A Memoir. Anglica: An International Journal of English Studies, 26(1), 149-164. https://doi.org/10.7311/0860-5734.26.1.10

Habib, M. A. R. (2005). A History of Literary Criticism from Plato to the Present. Malden, MA: Blackwell. https://doi.org/10.1002/9780470752142

Jameson, F. (1986). Third-World Literature in the Era of Multinational Capitalism. Social Text, 15, 65-88. https://doi.org/10.2307/466493

JanMohamed, A. (1985). The Economy of Manichean Allegory: The Function of Racial Difference in Colonialist Literature. Cultural Inquiry, 12(1), 59-87. https://doi.org/10.1086/448321

Neimneh, S., \& M. Obeidat. (2015). Narrativising Illness: Edward Said's Out of Place and the Postcolonial Confessional/Indisposed Self. Arab World English Journal, $3^{\text {rd }}$ Special Issue on Literature, 18-28. https://doi.org/10.2139/ssrn.2843951

Richter, D. (2007). The Critical Tradition: Classic Texts and Contemporary Trends (3rd ed.). Boston, MA: Bedford/ St. Martin's.

Said, E. (1979). Orientalism. New York: Vintage.

Said, E. (1993). Culture and Imperialism. New York: Vintage.

Said, E. (2000). Out of Place: A Memoir. New York: Alfred A. Knopf.

Said, E. (2002). Reflections on Exile. In Reflections on Exile and Other Essays (pp. 137-149). Cambridge, MA: Harvard UP.

Saleh, T. (1966). Mawsim al hijra ila al shamal (Season of Migration to the North). Beirut: Dar al Jil.

Spivak, G. (1990). The Post-Colonial Critic. In Sarah Harasym (Ed.), The Post-Colonial Critic: Interviews, Strategies, Dialogues (pp. 67-74). New York: Routledge. 


\section{Endnotes}

i A memorable literary counterpart on this difficult hybridity comes from al Tayeb Salih's Mawsim al hijra ila al Shamal (Season of Migration to the North) whereby the anonymous narrator enters the secret room of Mustafa Sa'eed (ironically carrying the same last name of Edward Said) to explore his hidden past and curious possessions. On the first page of a notebook, the life story of Mustafa Sa'eed written before his disappearance, the narrator finds this dedication which we translate from the original Arabic of the novel into English: "For those who see with one eye, speak with one tongue, and see things either black or white, either Eastern or Western" (1966, pp. 179-180). Like the fictional character with his namesake, Said could not speak one tongue or see things monodimensionally. Unhomeliness is the result of this difficult hybridity.

ii In their book Kafka: Toward a Minor Literature, Deleuze and Guattari argue that Kafka, as a Jew in Prague, wrote revolutionary or unconventional literature in German (a major language) rather than the established Czech. Among the main features of a minor literature they list are "deterritorialization of language, the connection of the individual to a political immediacy, and the collective assemblage of enunciation" (1986, p. 18). These can be paraphrased as linguistic dislocation, political nature, and a collective, universal value. All such characteristics find presence in Kafka's works. Arguably, and although Said did not write fiction, such features can be discussed with relation to this non-fictional memoir.

iii The term "bearing witness" has been used by Samuel Durrant in his reading of J. M. Coetzee's apartheid novels. Durrant interrogates the idea that literature "can offer a way of working through a collective history" and how Coetzee's novels written during the heyday of apartheid years in South Africa "bear witness to history at the very moment of its occurrence" (1999, p. 430). Durrant draws on the Freudian model that we are compelled to repeat what we fail to work through, contending that Coetzee's novels are "inconsolable" works of mourning.

iv This case was memorably depicted in the Palestinian stories of Ghassan Kanafani, particularly Men in the Sun.

\section{Copyrights}

Copyright for this article is retained by the author(s), with first publication rights granted to the journal.

This is an open-access article distributed under the terms and conditions of the Creative Commons Attribution license (http://creativecommons.org/licenses/by/4.0/). 